Section Editor

Mitchell S.V. Elkind, MD, MS

Jeffrey A. Switzer, DO Fenwick T. Nichols, MD

Address correspondence and reprint requests to Dr. Jeffrey A. Switzer, Department of Neurology, Georgia Health Science University, 112 15th

Street, Augusta, GA 30912 jswitzer@mcg.edu

\title{
Teaching NeuroImages: \\ Disappearing intraluminal thrombus of the carotid artery in reactive thrombocytosis
}

Figure 1 Ultrasound B-mode image of the left internal carotid artery (ICA) in longitudinal (top) and axial (bottom) views
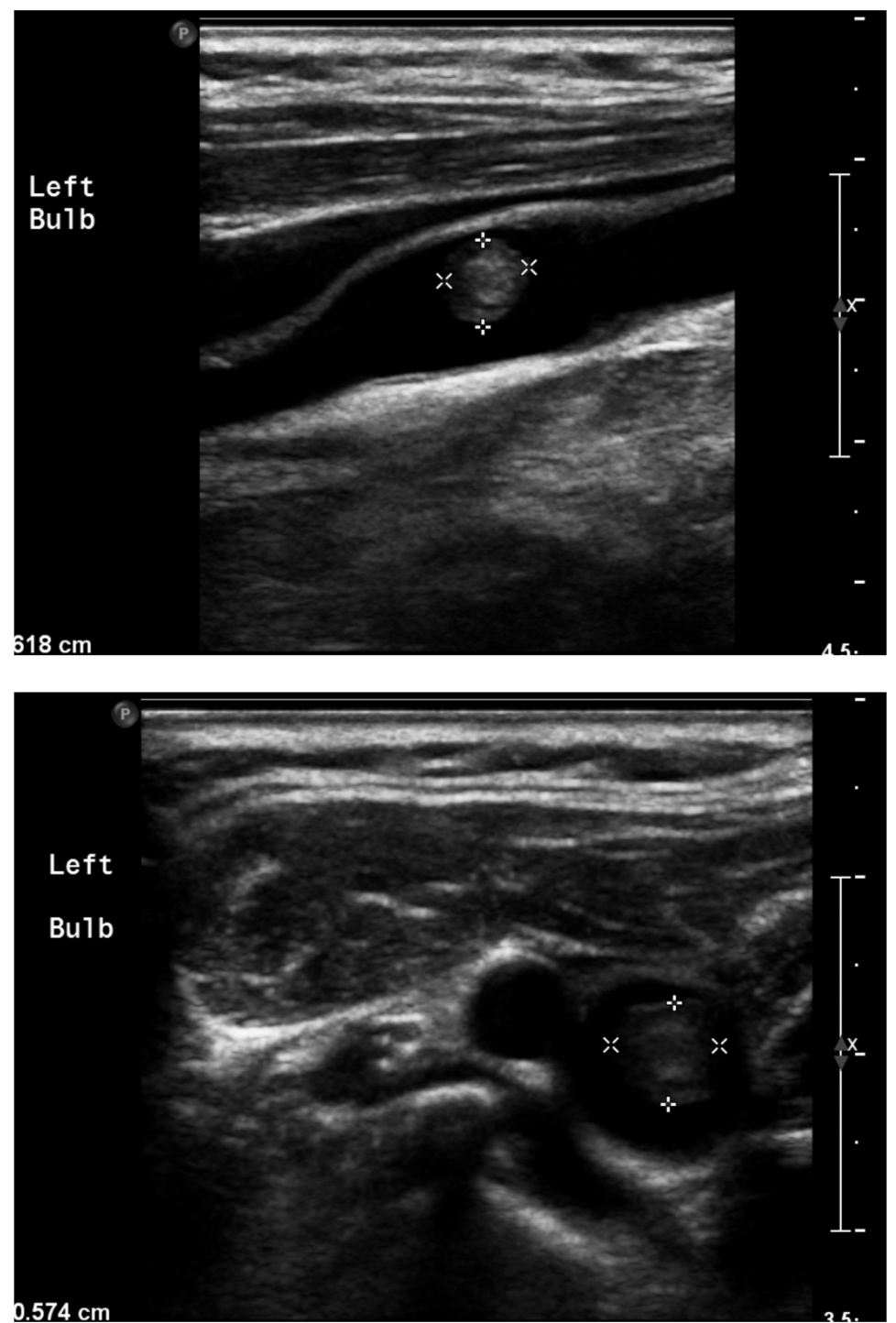

Slightly hyperechoic intraluminal thrombus appears adherent to the anterior wall of the ICA. There are no significant atherosclerotic changes of the underlying intimal-medial complex.

A 41-year-old woman with menorrhagia awoke with right hemiparesis. Brain MRI demonstrated punctate infarcts in the left middle cerebral artery territory.
Ultrasound revealed intraluminal thrombus in the left internal carotid artery bulb (figure 1 ). Hemoglobin was $6.9 \mathrm{~g} / \mathrm{dL}$ (normal $12.0-16.0 \mathrm{~g} / \mathrm{dL}$ ), platelet 
Figure 2 Ultrasound B-mode image of the left internal carotid artery (ICA) in longitudinal (top) and axial (bottom) views
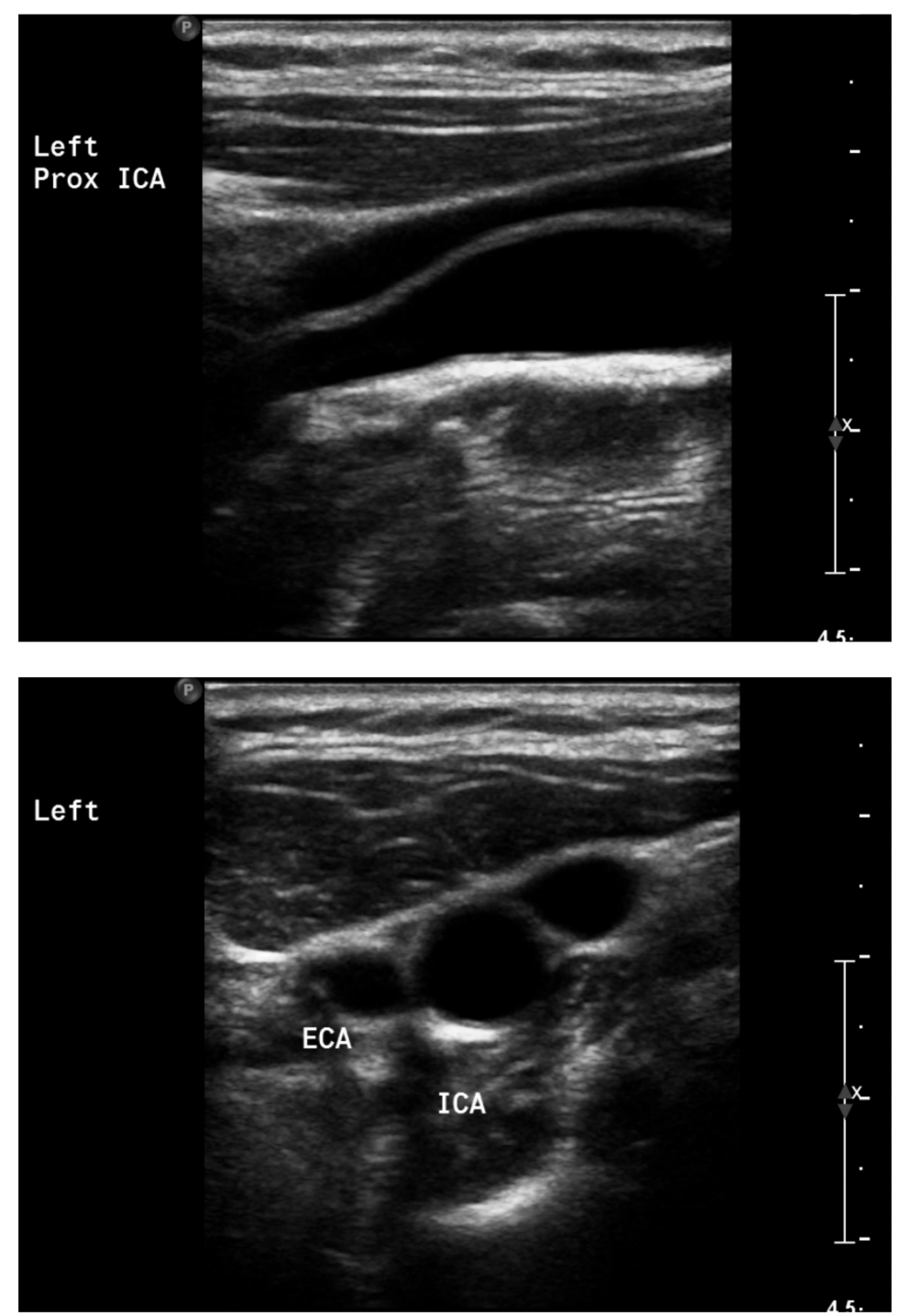

Thrombus has disappeared at 1 month.

count $1,557 \times 10^{3} / \mathrm{mm}^{3}$ (normal $\left.150-400 / \mathrm{mm}^{3}\right)$, and serum ferritin $2.20 \mathrm{ng} / \mathrm{mL}$ (normal $12-150 \mathrm{ng} /$ $\mathrm{mL})$. The patient was treated with platelet apheresis, packed erythrocyte transfusion, parenteral iron, and aspirin. Evaluation for other hypercoagulable states was negative. Repeat platelet count was $422 \times 10^{3} /$ $\mathrm{mm}^{3}$. At 1 month, the intraluminal thrombus had disappeared (figure 2).

Reactive thrombocytosis from iron deficiency anemia is a rare cause of stroke. ${ }^{1}$ In this setting, thrombus in the internal carotid artery may resolve with medical management. ${ }^{2}$

\section{DISCLOSURE}

Dr. Switzer has received funding for travel from Lundbeck Inc.; serves as a Review Editor for Frontiers of Teleneurology; and has received institutional support from the Georgia Health Science University Brain and Behavior Discovery Institute. Dr. Nichols has received funding for travel from Lundbeck Inc.; receives research support from the NIH; and is a founder in REACH, a telestroke system developed at MCG, which is now being marketed nationally.

\section{REFERENCES}

1. Keung YK, Owen J. Iron deficiency and thrombosis: literature review. Clin Appl Thromb Hemost 2004;10:387-391.

2. Akins PT, Glenn S, Nemeth PM, Derdeyn CP. Carotid artery thrombus associated with severe iron-deficiency anemia and thrombocytosis. Stroke 1996;27:1002-1005. 


\section{Neurology}

\section{Teaching NeuroImages: Disappearing intraluminal thrombus of the carotid artery in reactive thrombocytosis}

Jeffrey A. Switzer and Fenwick T. Nichols

Neurology 2011;76;e78-e79

DOI 10.1212/WNL.0b013e318216eb94

This information is current as of April 18, 2011

Updated Information \& Services

References

Subspecialty Collections

Permissions \& Licensing

Reprints including high resolution figures, can be found at: http://n.neurology.org/content/76/16/e78.full

This article cites 2 articles, 1 of which you can access for free at: http://n.neurology.org/content/76/16/e78.full\#ref-list-1

This article, along with others on similar topics, appears in the following collection(s):

All Cerebrovascular disease/Stroke

http://n.neurology.org/cgi/collection/all_cerebrovascular_disease_strok e

\section{Infarction}

http://n.neurology.org/cgi/collection/infarction

Ultrasound

http://n.neurology.org/cgi/collection/ultrasound

Information about reproducing this article in parts (figures,tables) or in its entirety can be found online at:

http://www.neurology.org/about/about_the_journal\#permissions

Information about ordering reprints can be found online: http://n.neurology.org/subscribers/advertise

Neurology ${ }^{\circledR}$ is the official journal of the American Academy of Neurology. Published continuously since 1951, it is now a weekly with 48 issues per year. Copyright Copyright $@ 2011$ by AAN Enterprises, Inc.. All rights reserved. Print ISSN: 0028-3878. Online ISSN: 1526-632X.

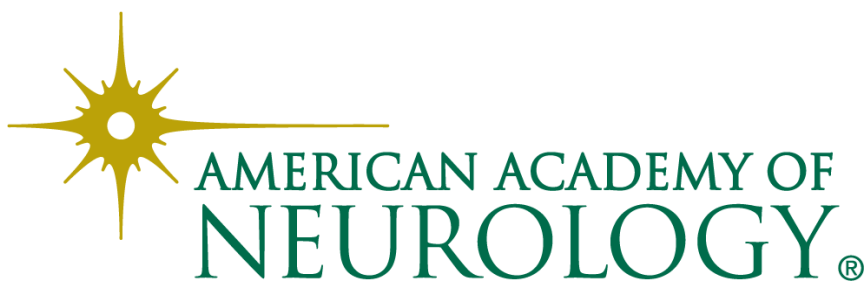

